\title{
Social Media Positioning Trend Analysis in 2017 Bangka Belitung Governor Election Campaign
}

\author{
Mr. Ibrahim ${ }^{1}$, Sandy Pratama ${ }^{2}$, and Mr. Rendy ${ }^{3}$ \\ ${ }^{I}$ Senior Lecturer of Department of Political Science, Bangka Belitung University, Balunijuk, Bangka, Indonesia \\ ${ }^{2}$ Department of Political Science, Bangka Belitung University, Sungailiat, Indonesia \\ ${ }^{3}$ Department of Political Science, Bangka Belitung University, Pangkalpinang, Indonesia \\ Iim_babel@yahoo.com,sandy-pratama@ubb.ac.id,rendy@mail.ugm.ac.id
}

Keywords: Campaign, Social Media, Trend.

\begin{abstract}
Recently in Indonesia, social media have been chosen as a campaign tools with a segment targeting technology users. The question then arises about how the campaign participants position social media in their campaign activities. This study applied semiotic approach to deepen on how the positioning trend would be. Social media is tended to be used as merely an image concern and highlighted the track record, while on the engagement dimension, monolog model and management by a team had been a practical choice. As facility dimension, social media had been a tool to deliver any ideas. While on dimension motive, social media is used as a self image facility, also actually a tool to strike down the opponents. This study showed that social media utilization trend had remained to be used for the sake of winning, there had not been a broader aspect regarding education and democracy capacity affirmation.
\end{abstract}

\section{INTRODUCTION}

A campaign in this case was examined in relation to social media use as a facility to look for political support, as many candidates started to enjoy it (see, for example, the study by Wibowo and Utari, 2009; Ardha, 2014; Frentasia, 2012).

However, the regulation of this kind of campaign have not been adequately regulated and supervised. Thus, it is still overly problematic within electoral politics dynamic. The question on how to control the social media in which it is very easy to access, having large coverage, and easier to distribute by everyone, either officially included within campaign team structure or other parties. Controlling social media is not as easy as controlling conventional campaign since its easiness accessibility by various parties and ironically its control is very weak.

This study would answer the major question on how actually social media positioning trend has been during campaign period by the candidates. The fact is the increase number of success team who use social media to win with an amazing result (see, for example, Caplan, 2013; Biswas, et.al., 2014; Karlsen and Enjolras, 2016; Filimonov, et.al., 2016; Gilmore and Howard, 2013; Stieglitz, et.al, 2012; Apuke and
Apollos, 2017). Using social for promotionand negation can be quickly, easily, and cheaply conducted via social media (see, for example, Vergeer and Hermans, 2013; Aine, 2016). Although it does not mean it effective, this study can illustrate as how social media usage framework placed during campaign

\section{METHOD}

This study used qualitative method by applying semiotic approach. Sobur (2009) quoted Sudibyo, Hamad, and Qodari stated that there are three dimensions in semiotic study, particularly social one; they are field of discourse, tenor of discourse, and mode of discourse. This study would review the messages delivered by all governor and vice governor candidates in social media. The review time setting would be during the campaign period held between February and April 2017. 


\section{RESULT AND DISCUSSION}

Bangka Belitung (Babel) Island Province consists of seven regencies/municipality, they are Pangkal Pinang, Bangka, Central Bangka, West Bangka, South Bangka, Belitung, and East Belitung. Political party configuration in this province is relatively a derivative of political party in national level. Governor election in 2017 was the fourth definitive governor election.

In 2017 Governor Election, there were four candidate couples competing, they were the candidate couple having serial number 1 Yusron Ihza and Yusroni Yazid $(Y Y)$, number 2 Rustam Effendi and M. Irwansyah (Babel Rumah Kite), number 3 Hidayat Arsani and Sukirman (Beriman), and number 4 Erzaldi Rosman and Abdul Fattah (Berkah). All couples competed under the law UU No. 10 Year 2016 in which one of them regulates all matters regarding campaign stipulation. However, the campaign in social media is not specifically regulated but merely reporting social media's account officially used by candidates. This study analyzed social media content used by four candidates.

\subsection{Media of Discourse}

The studies on social media indeed showed much on the user tendency in using all three social media mentioned (see, for example, Newman, 2010), though some studies abroad showed much more variations, for example: the use of Youtube, Vlog, Website, and others. Nevertheless, Facebook was more widely used by society in various age group and profession (compare to Smith, 2011). In addition to its easiness, the content that could be used also has variation with more various option menus. During the campaign period, Facebook accounts were the most milling about as campaign media in social media rather than other social media.

The variance of candidates in social media account noted that several accounts managed directly by using candidates' name, some of them were accounts that have team work characteristics. The interesting thing the governor candidates' name is generally used more as candidate trademark, while social media movement of vice governor candidate was relatively limited during campaign period.

\subsection{Field of Discourse}

Field of discourse is defined as what is being spoken or becoming major focus wishing to be delivered. In this study, field of discourse was understood as what the key message wanted to be delivered.

Based on social media review used by candidates, field of study was generally focused on every candidate couples' imaging. The candidate conducted socialization to people which contained a positive remark of themselves. Nevertheless, in some posts, some comments intended to deliver negative information distribution interest about other candidates also emerged.

For YY couple, social media was largely used to deliver Yusron's background and track record as an experienced official in national level. The experience of long staying in Japan was also connected to his readiness to be a local leader. Smart and qualified image had been the choices conveyed in mass media.

The Facebook status from 'Community of Young Bangka Belitung with YY', explains that Dr.Yusron was a former member of the Republic of Indonesia Parliament for 2 Period, and he was also believed to be the Indonesian ambassador to Japan and has full authority over the kingdom of Japan. 'Smart people choose Nol, i am smart voter YUSRON AND YUSRONI'.

While for Babel Rumah Kite, social media was fully contained with providing explanations about their success during their governor period. Rustam was the governor incumbent and re-nominated himself for the second period. The image as a common people and the closeness to president Jokowi:

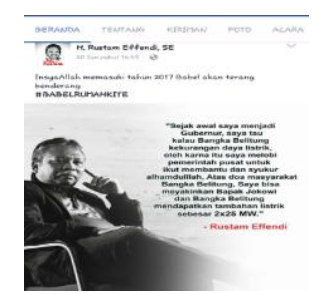

Figure 1: Incumbent candidate

The message contained:

'from the beginning I became a Governor, I understood that Bangka Belitung lacked electricity, so I lobbied the central government to help, and thank God for the prayer of the people in Babel, I was able to convince Mr. Jokowi as a president, and people eventually got an additional $2 x 25 \mathrm{MW}$ of electricity'

As for Beriman couple, they focused on local development discourse and related to development in economy. As a businessman figure, Hidayat Arsani has been known as public figure who is wealthy through his business. Therefore, he has welfare issue to play in social media. The diction 
sentence in a matter of employment and education was his major selling in many social media. The following was one of Hidayat Arsani post stated:

"..look for leaders who build and open jobs for their people by using personal money and not APBD money. Look for what has been proven for us, not unproven. 3 finger believers greetings must be our choice', HONEST, EXPRESS, AND ANTI CORRUPTION. 'REMEMBER DATE 15, choose number 3, Free for education and health"

Berkah couple itself build an image as the experienced figures in the regency they led and herd the society to assume their similar capacity in leading the province. The religious image was also shown by this couple. Berkah diction itself was related to someone and the creator. Moreover, this couple also built an image as close to the needy people.

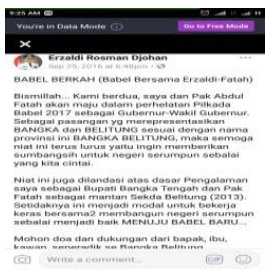

Figure 2: Status of candidate no.4

The message contained:

'...Blessing Babel Island, in the name of GOD, both of us, I and Pak Abdul Fattah will progress in the 2017 Babel Election event as governor and vice governor. This intention was also based on my experience as the middle Bangka regent and Fatah as the former secretary of Belitung. 'TOWARD THE NEW BABEL...'

The discourses constructed above were generally more to self image aspect and with very little content regarding the big dream they would carry. In fact, social media was used as a tool to build popularity through candidates' track record, rather than a tool to communicate and educate on whatthey would do if they were elected.

\subsection{Tenor of Discourse}

Tenor of discourse is the people talked about and involved in the discourse delivered. Data found in candidates' social media showed that candidate figures were generally the key focus in the messages delivered. Indeed, this referred to a hope that candidates must be positively perceived, thus it could emerge popularity to win the electability. Meanwhile, other parties generally involved were sympathizers and among the parties themselves.
There were two models used within this tenor of discourse, direct model of candidate and using other key figure by directly using an account other than candidate that was certainly the success team or candidate winning team.

$Y Y$ couple visually presented Yusron figure and his couple with a uniqueness in which many other parties even posted this candidate profile and provided a kind of testimony about them 'by design'. The following was a post from one of $Y Y$ couple supporter named Rasti Jayanti in her Facebook:

'...while in Japan, Yusron was not an ordinary student. This is an evidenced by its existence, including having been a campus correspondent for Tokyo for 7 years, being a researcher at the Tsukuba Advanced Research Alliance, being a lecturer at Nihon University, Japan, as well as a Japanese Justice Department political consultant. The most phenomenal is that when accompanied by doctoral Yusron managed to create phenomenal achievements by defeating the theory of Flying Geese Model from a famous Japanese Professor who is proud of the world. This is really AMAZING.

Whereas Babel Rumah Kite couple used many monolog styles directly from candidate in a form of informative and reflective post. Rustam Effendi as a governor candidate was much rised up by giving statements. For example, his statement regarding recent flood disaster in West Bangka Regency. His Facebook post stated:

'...I also concerned about the flood that hit our brother in West Bangka Regency. I urge people to be aware of the threat of flooding. I also asked all the officers, both the SAR, Tagana and volunteers to continue to monitor developments in the field...\#Babelourhome \#2 fingergreeting \#GREATBABEL...'

As for Beriman couple, they were used even more posts from other account to this couple's official one. The following was one example of account posts regarding Beriman couple.

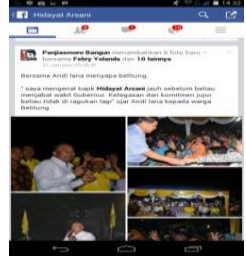

Figure 3: Candidate no.3 by sympathizer

'...with Andi lana greeting Belitung. " ... I knew Mr. Hidayat Arsani long before was as a vice Governor. His firmness and honest commitment 


\author{
are no doubt ... 'said Andi Lana to the residents \\ of Belitung...'
}

In the tenor of discourse aspect, the candidates generally used two major patterns, they were monolog style as if organizing their own account, and post style by involving other party to emphasize information about to be proclaimed for public. The formal language also showed that a post was seriously organized by certain people outside of the candidate for the sake of image.

The following was one of arguments to show social media indication organized by a team:.

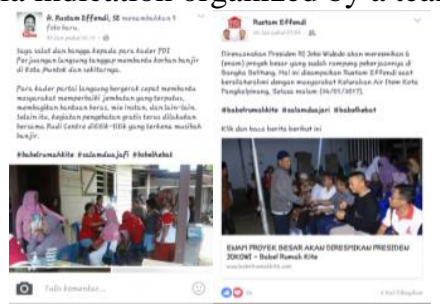

Figure 4: Candidate no.2 by incumbent

First picture (status) translation:

'...I salute and so proud of the PDI cadres for their immediate response to help flood victims in Muntok City and its surroundings. Party cadres immediately moved quickly to help people repair the broken bridges, distribute rice, instant noodles, and others. in addition, free medical treatment continues to be carried out with Rudi Center at points affected by floods...'

Second picture (status) translation:

'...It is planned that the Indonesian President Joko Widodo will inaugurate 6 (six) major projects that have been completed in Babel. This was conveyed by Rustam Effendi when he was in touch with the people of Airitam Pangkalpinang,

Tuesday night...'

These statuses above were posted by different accounts; however, they were under the same names. The posts were each other different in the content, i.e., the left post had direct private account motive and the right one was used to deliver information having 'other people' motive under the private name account.

\subsection{Mode of Discourse}

Mode of discourse referred to as how the messages were delivered by communicator and how the style was. This study identified sentence dictions conveyed. Based on the data review found, it was discovered that the trend of discourse was relatively various conveyed, started from figurative language to hide the real meaning, to the sentence diction explicitely, and directly targeted the expected thing.

$Y Y$ couple combined both of styles. In several posts, this couple firmly used invitation language to choose them also used implicit sentence to reveal Yusron 'class level'.

As for Babel Rumah Kite couple, they used more figurative sentences and less affirmative in asking the voters through social media. The language style was more reflective and tended to be defensive by presenting explanatory issues on every issue they lifted up. The following was a post from Rustam about tourism in his Facebook:

'...tourism in one of the upcoming Bangka Belitung mainstay sectors, efforts to realize tourism as proven by rising of Belitung's Special Economic Zone (SEZ) by President Jokowi. After being successful in Belitung, I sought similar areas in Bangka. The plan to propose the Bangka SEZ in the Matras tourism area to Pantai Rebo will be a priority. The hope is that the regional economy can be lifted again after a weak economy...'.

In Berkah couple, the sentence choice was more informative in terms of these couple activities. An invitation to vote would be more implicit.

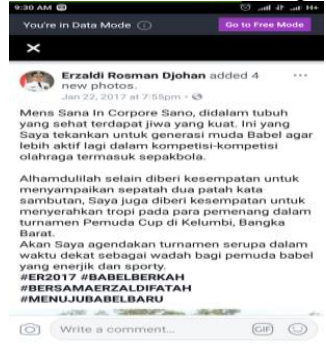

Figure 5: Candidate no.4

'...Sana In Corpore Sano, in a healthy body there is a strong soul. This is what I emphasize for the young generation of Bangka to be more active in sports competitions including football. Alhamdulillah, aside from being given the opportunity to say a couple of remarks, I was also given the opportunity to hand over trophies to the winners of the Youth Cup tournament in Kelumbi, West Bangka. .I will hold a similar

tournament in the near future as a place for energetic and sporty young men...'.

Based on social media review to fourth candidates above, it could be seen that language trend used was relative various. A direct and implicit style appeared to be the motive chosen. This study saw offensive character tended to be had by a candidate who was not an incumbent or being lead, while the opponent would tend to be defensive. 


\subsection{Motive of Discourse}

Motive of discourse in this study was understood as a main goal intended to be conceived by candidates via social media. Within four candidates, it could be seen that though their goal was to increase electability; however, social media use was constructed in the certain motive frame.

In $Y Y$ couple, social media was intended to create perception that this couple was smart, qualified, and experienced. There was a post from YY couple showing that YY criticized the policy that had not been optimum for Babel society welfare.

While for Babel Rumah Kite couple, social media was presented as an arena to reassure that their couple had been proved. The post contented much explained about his success in developing condusive economic climate.

As for Beriman couple, they used social media as a motive to delegitimate the recent condition occurred in constructing ideal leadership image for society.

As for Berkah couple, social media was a tool to build informative public perception on many candidates' ideas. More monolog post was chosen as a means to build perception. In addition, religious image was one of motives wishing to be built by this couple through their posts.

Therefore, it could be concluded that social media for candidate was positioned in various motives. Review on social media use as a campaign tool in this study was simplified as follows:

\begin{tabular}{|l|l|l|}
\hline \multirow{2}{*}{ Dimension } & \multicolumn{1}{|c|}{ Characteristic } & $\begin{array}{l}\text { User } \\
\text { Couple }\end{array}$ \\
\hline \multirow{2}{*}{$\begin{array}{l}\text { Media of } \\
\text { Discourse }\end{array}$} & Facebook & $1,2,3,4$ \\
\cline { 2 - 3 } & Twitter & 1,4 \\
\cline { 2 - 3 } $\begin{array}{l}\text { Field of } \\
\text { Discourse }\end{array}$ & Instagram & $2,3,4$ \\
\cline { 2 - 3 } $\begin{array}{l}\text { Tenor of } \\
\text { Discourse }\end{array}$ & Track record & $1,2,3,4$ \\
\cline { 2 - 3 } Mode of & Teamolog & $1,2,3,4$ \\
\cline { 2 - 3 } Discourse & Implicit & 2,4 \\
\cline { 2 - 3 } & Explicit & 1,3 \\
\cline { 2 - 3 } & Offensive & 1,3 \\
\cline { 2 - 3 } Motive of & Defensive & 1,3 \\
\cline { 2 - 3 } Discourse & Self image & 2,3 \\
\hline \multirow{2}{*}{\begin{tabular}{l} 
Opponent image \\
\hline
\end{tabular}} & & 1,3 \\
\hline
\end{tabular}

\section{Table 1 : The Dimension, Characteristic, and User}

One of the underlying problems in social media in a campaign was the campaign official inability to perform deep investigation on practices potentially disturbed election operation, at least diminished democratic quality through several social media having smell as imaging. Tambini, et.al (2017) stated that the recent social media as post-truth politics (compare to Gunn, 2017). Thus, this research said that there was a tendency of social media use in governor election to be directed into more pragmatic interests; it had not been ideologic, though not all of them contained hoax.

Social media had remained positioned as a tool to achieve electoral interest, especially on how to influence voters through arenas of image, delegitimization, reflection and others as the major orientation and was not as a tool to educate public.

However, several literature reviews and studies of social media conducted so far have generally discussed the role of social media in the vortex of electoral politics, whether as a marketing tool, arena and platform for discussion, debating, critiquing or sharing, broadcasting politically-related activities, agenda-setting, persuading, influencing, and mobilizing voters (see, i.e, Norris, 2003; Muntean, 2015; Enli, 2016; Filimonov, Uta, and Jakob, 2016; Stier, Arnim, Haiko \& Markus, 2018). However, most of those studies tend to deepen analysis to one or two of social media only.

The position of this study eventually is in line with previous researches. It has enriched to the previous studies which elaborated to the role of social media. In this study, it turns out that the most widely use social media is Facebook.

The interesting things left from this study were the limited efforts to explore social media effectivity in a campaign, especially for example on how much the coverage edited by and how much the influenced. On the other side, Stieglitz (2012) study emphasizing the importance of social media campaign related to e-participation.

At glance, social media was still perceived as a tool to proclaim an invitation to vote certain candidate, thus the future studies will need to discuss on how deep its contribution for social politic quality development in the middle of electoral interest tugging.

\section{CONCLUSION}

There are some interesting things. Firstly, the social media used relatively various; however, facebook was the most popular one and mostly used in Indonesia, especially for low class society. Secondly, social media had remained limited for the use of image interest and accentuated candidates' 
track record rather than demonstrated the ideas as where they would bring their region if someday they would have been elected. Social media was mostly filled with image jargon having very few vision and mission (compare to Hadji, 2016). Thirdly, there were two communication models performed by a candidate that was through monolog model and team model managed by other people having affiliation to promote the candidate. Fourth, social media was generally used with various language styles. Fifthly, social media application major motive was a positive self image and also used as a tool to drop the opponent's image.

This study found that social media had remained limited in usage for the sake of electoral interest. Education and performance to ask public participation were not included. In the future, there will be leaving a gap to drive a study of social media effectivity in a campaign and to further probed on how the social media influence in expanding a participation movement based on cyberspace.

\section{REFERENCES}

Aine, Ruth, Social Media Usage in Uganda and how it affects Political and Social Communication in Reality Check, Assesing The Impact of Social Media on Political Communication and Civic Engagement in Uganda edited by Mathias Kamp, Konrad-Adenauer-Stiftung, Kampala, (2016).

Apuke, Oberiri Destiny and Ivo Nkasire Apollos, Public Perception of The Role of Facebook Usage in Political Campaigns in Nigeria in International Journal of Community Development and Management Studies, Vol. 1, pp. 85-102, (2017).

Ardha, Berliani, Social Media sebagai Media Kampanye Partai Politik 2014 di Indonesia, Jurnal Visi Komunikasi Volume 13, No. 01, pp. 105-120, Mei, (2014).

Biswas, Aindrila, Nikhil Ingle, and Mousumi Roy, Influence of Social Media on Voting Behavior in Journal of Power, Politics \& Governance, Vol. 2, No. 2, pp. 127-155, June (2014).

Caplan, Julia, Social Media and Politics: Twitter Use in the Second Congressional District of Virginia in The Elon Journal of Undergraduate Research in Communications, Vol. 4, No. 1, pp. 5-11, Spring, (2013).

Filimonov, Kirill and Uta Russmann and Jakob Svensson, Picturing the Party: Instagram and Party Campaigning in the 2014 Swedish Elections, in Social Media + Society, pp. 1 -11 July-September, (2016).

Frentasia, Jennifer, Social Media and Electoral Strategies: Evidence from Indonesian Legislative Branch, A Senior Honors Thesis, Department of Political Science, University of California, San Diego, (2012).

Gilmore, Jason and Philip N. Howard, Does Social Media Make a Difference in Political Campaigns? Digital Dividends in Brazil's 2010 National Elections, Working Paper 2013-2 University of Washington, (2013).

Gunn, Enli, Twitter as arena for the authentic outsider: exploring the social media campaigns of Trump and Clinton in the
2016 US presidential election, Pre-publication version European Journal of Communication Vol 32, Issue 1, pp. 50 $-61,(2017)$.

Hadji, Ahmed, Breaking Boundaries: The Opportunities for using Social Media in Civil Society Networking, Activism and Civic Engagement in Reality Check, Assesing The Impact of Social Media on Political Communication and Civic Engagement in Uganda edited by Mathias Kamp, Konrad-AdenauerStiftung, Kampala, (2016).

Karlsen, Rune and Bernard Enjolras, Styles of Social Media Campaigning and Influence in a Hybrid Political Communication System: Linking Candidate Survey Data with Twitter Data, in The International Journal of Press/Politics, Vol. 21 (3), pp. $338-357$, (2016).

Muntean, Alina, The Impact of Social Media Use on Political Participation. Master thesis in Corporate Communication, University of Aarhus, August 2015.

Newman, Nic, \#Ukelection2010, mainstream media and the role of the internet: how social and digital media affected the business of politics and journalism, Working Paper, Reuters Institute for The Study of Journalism, University of Oxford, (2010).

Norris, Pippa. Digital Divide Civic Engagement, Information Proverty and the Internet Worldwide. Cambridge: Cambridge University Press.

Smith, Aaron, $22 \%$ of online Americans used social networking or Twitter for politics in 2010 campaign, Republicans catch up to Democrats in social media use for politics, Pew Research Center, (2011).

Sobur, Alex, Analisis Teks Media, Suatu Pengantar untuk Analisis Wacana, Analisis Semiotik, dan Analisis Framing, PT. Remaja Rosdakarya, Bandung, (2009).

Stieglitz, Stefan, et.al., Usage Of Social Media For Political Communication in Pacific Asia Conference on Information System (PACIS), (2012).

Stier, Sebastian, Arnim Bleier, Haiko Lietz and Markus Strohmaier, Election Campaigning on Social Media: Politicians, Audiences, and the Mediation of Political Communication on Facebook and Twitter, Journal Political Communication Vol 35, Issue 1, pp.50, (2018).

Tambini, Damian, et.al., Media Policy Brief 19, The new political campaigning, LSE Media Policy Project Series Editors: Damian Tambini and Emma Goodman, (2017).

Vergeer, Maurice and Liesbeth Hermans, Campaigning on Twitter: Microblogging and Online Social Networking as Campaign Tools in the 2010 General Elections in the Netherlands, Journal of Computer-Mediated Communication 18, pp. 399-419, (2013).

Wibowo, Arief dan Dyah Retno Utari, Analisis Isi (Content) Blog sebagai Media Kampanye Calon Anggota Legislatif (Caleg) pada Pemilu 2009, Paper pada Seminar Nasional Informatika 2009 UPN "Veteran" Yogyakarta, 23 Mei, (2009). 